\title{
The Privateering Debate in Revolutionary America
}

\section{Michael J. Crawford}

Comme les historiens d'aujourd'hui, les participants à la Guerre d'Indépendance américaine ont discuté les mérites et les démérites de la guerre de course - combien elle a endommagé le commerce britannique; à quel point elle a subjugué les ressources britanniques alors que la marine royale déployait ses bâtiments pour défendre les navires marchands britanniques contre les croiseurs, armés et privés, américains; les difficultés qu'elle a produites pour les marines Continentales et du Nord de par la concurrence pour l'embauche de marins et pour les approvisionnements navals; et le mélange de patriotisme et de vénalité dans sa motivation - mais sans l'avantage de rétrospection des historiens. Sans savoir comment finirait la lutte, ils ont dî former leurs opinions sur des évidences partielles et sur la spéculation.

Historians still debate the relative merit of privateering during the American War of Independence. Key to this debate is understanding how damaging it was to British commerce; the extent to which it strained the Royal Navy's resources; the difficulties it produced for the Continental and state navies by competing for seamen and naval stores; and the mix of patriotism and venality in its motivation. The war's participants debated the same issues historians debate today, but without the historians' advantage of hindsight: not knowing how the struggle would end, they had to form their views based on partial evidence and speculation.

What did contemporary American Revolutionaries think? Did they shun privateersmen as disreputable characters interested only in profit and devoid of patriotic feeling and consider privateering as unscrupulous and akin to piracy? Or did they embrace privateersmen as heroic defenders of liberty and endorse commerce raiding as a valuable contribution to the war effort? This question is more complex than it first appears, and its answer is just as complex. Although critics raised strong argumentsmostly practical, but some based on ethical and moral considerations - their criticisms never posed a serious threat of putting an end to privateering once the Continental Congress had decided to authorize it. The prevalent view was that privateering was a valuable means of funnelling the resources controlled by private interest into the public cause.

The European tradition of privateering originated in the Middle Ages when monarchs issued letters of marque and reprisal to merchants who complained of 
peacetime losses from spoliations at sea by foreign subjects. Letters of marque authorized merchants to plunder the ships of a specific kingdom in order to recoup those losses. Medieval monarchs also soon found that letters of marque to make economic war on an enemy was an inexpensive way of augmenting their naval forces in wartime. By the time of the American War of Independence, a large body of practice generally recognized as part of the laws of nations had developed. Letters of marque, now issued exclusively in times of war, specified the captain, the name of the ship, the size of its crew, and the nature of its armament, and identified the nation or nations whose ships the sovereign was authorizing capture. A ship carrying a letter of marque was also known as a letter of marque if the principal aim of a voyage was trade and the capture of enemy merchantmen was secondary. A ship carrying a letter of marque whose principal aim was commerce raiding was called a privateer, meaning a privately-owned warship authorized to make prize of enemy property at sea. Generally, a privateer was more heavily armed and carried a larger crew than a letter of marque ship. International law recognized the right of privateers and letters of marque to make prize of enemy property at sea; these licensed sea raiders were not authorized to plunder property ashore. When a privateer successfully stopped and boarded another ship at sea, its officers were to examine the ship's papers for evidence of ownership. If the officers had good reason to believe that the ship and cargo were owned by subjects of the enemy nation named in the privateer's letter of marque, the privateer would seize the vessel, place a prize master and prize crew on board and send it into port for trial at an admiralty court. European nations were not agreed on whether enemy property found in a neutral ship was a legal prize. Britain favored seizing enemy property aboard neutral ships, whereas France among others insisted that "free ships make free goods." Before trial, the privateer was to publish a "libel" against the ship and cargo in the newspapers. Legal ownership of the ship and cargo would not transfer until the court ruled on whether the "prize" was indeed enemy property and legally captured. For this reason, the privateer's crew was not supposed to "break bulk," that is, open up or remove captured cargo, before trial. If the court found for the captors, it would condemn the ship and cargo and order it sold by the sheriff. After deducting for court costs, port fees, and the like, the proceeds of the sale would go to the owners of the privateer to be divided with the privateer's officers and crew according to a formula agreed to in shipping articles signed at the commencement of the cruise. ${ }^{1}$

More than two thousand American vessels engaged in privateering during the Revolutionary War, and perhaps as many as three thousand. Incomplete records prevent a more accurate count. The Continental Congress commissioned at least 1,700, the Commonwealth of Massachusetts 600, and other states fewer numbers. Mark M. Boatner III suggests that it is "not too meaningful to state the number commissioned," given that most privateers sailed on but a single cruise. Whatever the exact number, the American privateering enterprise was substantial. Testimony in the House of Lords in February

1 For prize law, see Henry J. Bourguignon, The First Federal Court: The Federal Appellate Prize Court of the American Revolution 1775-1776 (Philadelphia, 1977), and Donald A. Petrie, The Prize Game: Lawful Looting on the High Seas in the Days of Fighting Sail (Annapolis, MD, 1999). 
1778 stated that there were 173 active American privateers known to the British, carrying 2,556 carriage guns, and an estimated 13,540 seamen. Whereas Boatner states that between 1775 and 1783 American privateers captured about 600 British vessels, among which 16 were Royal Navy men-of-war, the total valued at about \$18 million, William S. Casey counted 3,176 British vessels taken by American privateers between 1775 and 1782, of which 893 were retaken or ransomed. During debate in the House of Lords in February 1778, when the war would have another five years to run, it appeared from the meticulously maintained register of ships kept at Lloyd's Coffee House that "the number of ships lost by capture, or destroyed by American privateers, since the commencement of the war," was 733 , valued, with their cargoes, at some $£ 2$ million. William James Morgan judges that the economic effects of American privateering were offset by American ships captured by the British. When administration supporters in the House of Lords made a similar argument during the February 1778 debate on the effects of American privateering, opposition peers pointed out the absurdity of the conclusion "that because a number of vessels had been taken, they were to be balanced by another number of vessels taken, on the other side, and consequently no loss to the nation on the whole, . . . for if we were not at war with America, the value of all these cargoes in the circuitous course of trade must center with Great Britain." 2

A review of some of the most relevant literature will convey a sense of the contours of the debate among historians as to whether privateering helped or hurt the cause of American independence. On the one extreme of the spectrum of judgments as to the measure of privateering's contribution to the American war effort stands Edgar Stanton Maclay. Writing in 1899, Maclay asserted that it was the American privateers' "attack on British commerce that struck the mortal blows to British supremacy in America - not Saratoga nor Yorktown." ${ }^{33}$ Maclay argues that privateering so disrupted commerce that British merchants pressured Parliament to end the war. Few historians today believe that British foreign policy during the American Revolution was driven by the mercantile classes. Writing nearly seven decades after Maclay, Mark Mayo Boatner III represents several historians at the other end of the spectrum of opinion who hold that the privateers accomplished little of value: "Privateers were little more than licensed pirates who contributed little to the American cause."

The greatest disservice to the understanding of privateering during the American

2 Mark Mayo Boatner III, Encyclopedia of the American Revolution (New York, 1966), s.v., Privateering; Michael Scott Casey, "Rebel Privateers-the Winners of American Independence," (MA thesis, U.S. Army Command and General Staff College, 1990), 65; William James Morgan, “American Privateering in America's War for Independence," in Course et piraterie: Etudes présentées à la Commission Internationale d'Histoire Maritime à l'occasion de son XVe colloque international pendant le XIVe Congrès International des Sciences historiques (San Francisco août 1975) (Paris, 1975); "Proceedings in the Lords respecting the Commercial Losses occasioned by the American War," Naval Documents of the American Revolution, William B. Clark, et al., eds. (Washington, DC, 1964) XI, 967-71, 985-87, 994-96.

3 Edgar Stanton Maclay, A History of American Privateers (New York, 1899), xi.

4 Boatner, Encyclopedia of the American Revolution, s.v., Privateering. 
Revolution is the frequently repeated piece of nonsense that privateering was licensed piracy. ${ }^{5}$ Privateering and piracy were both forms of commerce raiding, it is true. However, whereas pirates were international outlaws involved in highly criminal behavior, privateers pursued on the behalf of a nation a form of warfare that the law of nations recognized as legitimate. If commerce raiders carrying letters of marque behaved piratically, operating outside the rules, they were liable to trial and execution as pirates. Some, but not all, deviations from the rule of law by privateersmen were piratical acts. Plundering ashore, cruel treatment or murder of prisoners, capturing ships of nations not authorized in the letter of marque, and failure to bring a captured vessel to trial might justify charges of piracy. Breaking bulk, on the other hand, was theft, not piracy. A captured privateer had all the rights of a prisoner of war possessed by captured personnel enlisted in a national army or navy. Linking privateering to piracy suggests that privateers, like pirates, were motivated primarily by greed and were little concerned with making a positive contribution to the war effort.

Jonathan R. Dull has given an interesting twist to the debate by arguing that the Revolutionaries would have done better if they had forgotten about creating the Continental and state navies and instead had put all their efforts at sea in privateers. ${ }^{6}$ In answer to Dull, William S. Dudley and Michael A. Palmer provide, among other arguments, calculations demonstrating that ship for ship the Continental Navy was more effective at commerce raiding than were privateers. ${ }^{7}$ Richard Buel Jr. reasons that privateers could be as effective as official navies in commerce raiding and in clearing local waters of enemy privateers, but, tallying ship captures and recaptures by the Americans and the British, he concludes that commerce raiding had little "effect on the overall balance of naval power." ${ }^{8}$

Nowhere in his magisterial The War for America, 1775-1783 does Piers Mackesy directly address the issue of the effectiveness of American privateers, but he scatters through his text material that demonstrates the powerful influence that privateering had on British policy. Because "contractors were unwilling to arm ships or expose their cargoes to rebel privateers," the Treasury had to hire its own victuallers to feed the army in America, adding yet another official competitor for British shipping and seamen. At the outset of the war, having to deal with the "swarms of American privateers" left the Royal Navy "little to spare for commerce-raiding." Admiral Lord Richard Howe was

5 The linking of privateering and piracy in the titles of professional conference sessions and books promotes this misunderstanding. For criticisms of linking the two forms of commerce raiding, see John Franklin Jameson, Privateering and Piracy in the Colonial Period (New York, 1923; reprint ed., 1970), viii-ix, and William James Morgan, “American Privateering in America's War for Independence."

6 Jonathan R. Dull, "Was the Continental Navy a Mistake?” American Neptune XLIV (1984): 167-170.

7 William S. Dudley and Michael A. Palmer, "No Mistake About It: A Response to Jonathan Dull," The American Neptune XLV (1985): 244-248.

8 Richard Buel Jr., In Irons: Britain's Naval Supremacy and the American Revolutionary Economy (New Haven, CT, 1998), 95-96. 
inclined to leave American fishermen alone for fear of driving them to privateering. The threat of privateers to British shipping created a demand for convoys that strained the Royal Navy's resources. American privateers posed a verifiable danger to British seaborne communications, at least once capturing important British dispatches. The inability of the British West Indian sugar islands to feed themselves made them highly vulnerable to privateers that haunted their supply routes. This vulnerability forced the British to detail cruisers to the Caribbean to protect British merchantmen who refused to wait for convoys. David Syrett argues similarly that the threat of capture by privateers contributed to the increase in British freight rates, increased shipping expenses because of changing patterns in the transport service, and increased the difficulties and costs of transporting military supplies to North America faced by the Navy Board, who dreaded capture of those supplies lest they end up supporting American forces in the field. Mackesy's and Syrett's works suggest that in assessing the contributions of privateering to the American war effort one should do more than, like a counting-house clerk, balance captures against recaptures or calculate the value of losses to the British economy. The significance of American privateering extended beyond its pushing hard-hit London merchants to promote peace sentiment in Parliament. In the face of Mackesy's and Syrett's evidence, it is hard to sustain the position that American privateers had a negligible effect on the British conduct of the war. ${ }^{9}$

The movement to authorize privateering began in Massachusetts not long after the shooting war began in 1775. By October, Massachusetts ship owners were petitioning the Provincial Congress for letters of marque.$^{10}$ Elbridge Gerry, distressed that the British supplied their forces in Massachusetts by sea with impunity, asked "can we doubt the propriety of encouraging individuals by giving them the advantage resulting from their reprisals, when it is certain that other plans will not meet with such success as will probably attend this?"11 On 1 November the Massachusetts government adopted an act for the issuance of commissions to private armed ships authorizing captures of vessels actively engaged in depredations along the American seacoast or employed in supplying the hostile forces, and to recapture ships taken by the enemy. The issuance of letters of marque was an act of sovereignty. In order to avoid the implication that Massachusetts was asserting its independence, the Massachusetts lawmakers included a preamble grounding the act on the powers to levy war in self defense granted by Massachusetts's royal charter. Massachusetts's Revolutionary government saw privateering as a useful means to prevent supplies from reaching the British forces occupying Boston and to

9 Piers Mackesy, The War for America, 1775-1783 (1964; reprint ed., Lincoln, NE, 1993), 67, 99, 101, 173, 198, 228. David Syrett, Shipping and the American War 1775-83: A Study of British Transport Organization (London, , 1970), 63, 131, 139, 216.

10 Journal of the Massachusetts House of Representatives, 2 Oct. 1775, Clark, Naval Documents of the American Revolution, II: 269; Ivory Hovey to the Massachusetts General Court, 5 Oct. 1775, ibid., II: 304; and Report of the Committee Upon the Petition of Ivory Hovey, 6 Oct. 1775, ibid., II: 323.

11 Elbridge Gerry to Samuel Adams, 9 Oct. 1775, Clark, Naval Documents of the American Revolution, II: $369-370$. 
retaliate for British depredations against American shipping and coastal settlements. ${ }^{12}$

In February 1776, inhabitants of Philadelphia petitioned the Continental Congress for permission to fit out privateers, in order to indemnify them for losses from depredations by British men-of-war. After debating the issue ${ }^{13}$ _ Josiah Bartlett, delegate from New Hampshire, thought it "very hard that Brittain is Seizing all American vessells and the Americans are not permitted to return the Compliment"14_Congress passed a resolution on 23 March to commission privateers, authorizing captures not just of enemy warships and supply vessels but of all vessels that were the property of inhabitants of Great Britain. Congress asserted that this act was "necessary to provide for [the United Colonies'] defense and security, and justifiable to make reprisals upon their enemies." 15 John Adams, a Massachusetts delegate to Congress and a proponent of both privateering and independence, saw the former as a step toward the latter. ${ }^{16}$

Once the mechanisms for issuing letters of marque were in place, the two factors that principally influenced the debate over privateering and attitudes toward privateersmen became the perceived effects of the practice and the behaviour of its practitioners.

The first returns on privateering proved favourable. On 5 June 1776, Philadelphia's Robert Morris, writing for Congress's Committee of Secret Correspondence, reported that privateers had lately taken several valuable prizes. He further indicated that he expected many more West Indian vessels to be taken during the summer, giving Great Britain cause to repent the Prohibitory Acts that had authorized the seizure of American ships, "especially as they have much more property to loose than we have." 17 In December, Morris observed that, owing to the large investments in privateering in the northeastern states, "their Imports with their Captures have been so considerable, that they are better Supplied than any other part of America." 18 John Adams and his wife, Abigail, gloried in the success of the privateers, especially those of Massachusetts. In August 1776 John wrote Abigail, "Thousands of schemes for Privateering are afloat in American Imaginations. . . . Out of these Speculations . . some profitable Projects will grow." 19 Abigail replied, "I think we make a fine hand at prizes," and a few weeks later observed, "the Rage for privateering is as great here as any where and I believe the success has been as great." 20

12 Massachusetts Act Authorizing Privateering and Creating Courts of Admiralty, ibid., II: 834839; Gardner W. Allen, Massachusetts Privateers of the Revolution (Boston, MA, 1927), 2431.

13 Diary of Richard Smith, Clark, Naval Documents of the American Revolution, IV: 398.

14 Josiah Bartlett to John Langdon, 21 Feb. 1776, ibid., IV: 31-32.

15 Journal of the Continental Congress, 23 March 1776, ibid., IV: 477-480.

16 John Adams to Abigail Adams, 12 April 1776, ibid., IV: 788-789.

17 Robert Morris to Silas Deane, 5 June, 1776, ibid., V: 384.

18 Robert Morris to Silas Deane, 20 Dec. 1776, ibid., VII: 532.

19 John Adams to Abigail Adams, 12 Aug. 1776, ibid., VI: 158.

20 Abigail Adams to John Adams, 25 Aug. and 7 Sept. 1776 (two letters), ibid., VI: 299, 731. 
While Abigail Adams was praising "the Rage for privateering," others were beginning to rue it for its baneful influence on other elements of the war effort. During 1776 critics of excessive privateering complained of four such detrimental effects. First, the preoccupation of moneyed merchants with fitting out privateers and buying prize cargoes drove up the cost of borrowing money. ${ }^{21}$ Second, privateers' demands produced a scarcity of carriage guns available to arm public warships and increased their price excessively. ${ }^{22}$ Third, the more attractive chances for prize money and other terms of service in privateers made it difficult to man warships in the Continental NavyCommodore Esek Hopkins suggested increasing sailors' shares in Continental Navy prizes. ${ }^{23}$ And fourth, so many young men were engaged in privateers that the states were having difficulty filling their quotas for the Continental Army. ${ }^{24}$ These complaints, particularly the latter two, would reappear continually throughout the war. ${ }^{25}$

To counter the competition for men that privateers gave the army and navy, state governments, particularly in the northeast, placed temporary embargoes on privateering as circumstances required. ${ }^{26}$ In April 1777, for instance, the Massachusetts General Court placed an embargo on privateers' shipping men from any town that had not raised its quota of soldiers for the Continental Army. ${ }^{27}$ John Adams thought such actions were wrongheaded. Writing from Philadelphia to a friend in Boston, he argued:

I hope your Embargo is off, before now, that the Privateers may have fair Play. Indeed I am sorry it was ever laid. I am against all Shackles upon Trade. Let the Spirit of the People have its own Way, and it will do something. I doubt much whether you have got an hundred Soldiers the more for your Embargo, and perhaps you have missed Opportunities of taking many Prizes and several Hundreds of Seamen. ${ }^{28}$

21 Meshech Weare to Matthew Thornton and William Whipple, 14 Dec. 1776, ibid., VII: 480.

22 Thomas Cushing to Robert Treat Paine, 9 Sept. 1776, ibid., VI: 755; Commodore Esek Hopkins to the Continental Marine Committee, 10 Sept. 1776, ibid., VI: 770.

23 Commodore Esek Hopkins to the Continental Marine Committee, 22 and 30 Sept., and 24 Oct. 1776 (three letters), ibid., VI: 949, 1055-1056, 1399; Capt. John Paul Jones to Robert Morris, 17 Oct. 1776, ibid., VI: 1303.

24 Cotton Tufts to John Adams, 17 June 1776, ibid., V: 580-82; Isaac Smith to John Adams, 6 Aug. 1776, ibid., VI: 77; Maj. Gen. Charles Lee to Meshech Weare, 27 Nov. 1776, ibid., VII: 306-307; Benjamin Rush to Richard Henry Lee, 21 Dec. 1776, ibid., VII: 543-544.

25 For example, Capt. Thomas Thompson to the New Hampshire General Assembly, 4 June 1777, ibid., IX: 16; Portsmouth Committee of Safety to New Hampshire Committee of Safety, 7 July 1777, ibid., IX: 230; William Whipple to Robert Morris, 6 and 21 July 1777 (two letters), ibid., XI: 1147-1148, and IX: 308; Journal of the New Hampshire Council, 9 March 1778, ibid., XI: 547; John Bradford to Continental Marine Committee, 25 March 1778, ibid., XI: 781-782.

26 For calls for such embargoes, see Cotton Tufts to John Adams, 17 June 1776, ibid., V: 580, and Gov. Jonathan Trumbull to Gen. George Washington, 21 Feb. 1777, ibid., VII: 1255.

27 Allen, Massachusetts Privateers, 42.

28 John Adams to James Warren, 6 April 1777, Clark, Naval Documents of the American Revolution, VIII: 282. 
By the spring of 1777 Adams could have read Adam Smith's 1776 Wealth of Nations, ${ }^{29}$ for Adams's argument echoes Smith's endorsement of the invisible hand of a free market economy. The genius of privateering was that the pursuit of private profit by many individual privateers produced a substantial public benefit - a powerful blow to enemy commerce. When each pursued his own good, the good of the whole was advanced.

As early as 1776 observers were voicing abhorrence of the base motives and underhanded maneuvers they detected among those financially interested in privateers. Continental Navy Captains John Paul Jones at Newport, Rhode Island, in October 1776, Nicholas Biddle at Charleston, South Carolina, in September 1777, and Hector McNeill, in Boston in October 1777, all protested against privateers that enticed away their men. ${ }^{30}$ At Providence in November 1776, Esek Hopkins, commodore of the Continental fleet, asserted, "near one third of the Men which have been Shipp'd and received their Month's pay, have been one way or another carried away in Privateers." Hopkins fumed when a motion in the Rhode Island General Assembly to place an embargo on privateering until the Continental fleet had been manned failed "owing to a Number of the Members being deeply involved in Privateering." 31 In Portsmouth, New Hampshire, Captain Thomas Thompson criticized Continental Agent John Langdon for manning his privateer while the Continental Navy frigate Raleigh was manning. ${ }^{32}$ Similarly, John Paul Jones found that "even some of the Gentlemen Appointed to fit out the New Frigates are concerned in Privateers and not only Wink at, but encourage, and Employ deserters from the Navy." 33

Of all the Continental Navy officers, Jones impugned the character of privateersmen and privateer owners with the greatest vehemence. "The common Class of mankind," he judged, "are Actuated by no nobler principle than that of Self-Interest - this and this Only determines all Adventurers in Privateers; the Owners as well as those whom they Employ." 34 Proposing that "Publick Virtue is not the Characteristick of the concerned in Privateers," he denounced the "base Conduct practiced by those licensed Robbers." The particular moral failing Jones bemoaned in "the sordid Adventurers in Privateers," was their releasing prisoners taken in prizes rather than bringing them in to be exchanged for American sailors held in British prisons. ${ }^{35}$

Jones's disdain for privateersmen was not merely a reflection of his interest as a

29 Adam Smith, An Inquiry into the Nature and Causes of the Wealth of Nations (Edinburgh, 1776).

30 Capt. John Paul Jones to Robert Morris, 17 Oct. 1776, Clark, Naval Documents of the American Revolution, VI: 1303; Capt. Nicholas Biddle to Robert Morris, 1 Sept. 1777, ibid., IX: 863-864; Capt. Hector McNeill to the Continental Marine Committee, 9 Oct. 1777, ibid., $\mathrm{X}: 85$.

31 Commodore Esek Hopkins to Continental Marine Committee, 2 Nov. 1776, ibid., VII: 17.

32 Capt. Thomas Thompson to the New Hampshire Committee of Safety, 6 Feb. 1777, in ibid, VII: 1114-1115.

33 John Paul Jones to Joseph Hewes, 31 Oct. 1776, ibid., VI: 1474.

34 John Paul Jones to Robert Morris, 17 Oct. 1776, ibid., VI: 1303.

35 John Paul Jones to Robert Morris, 11 Dec. 1777, ibid., X: 1091-1092. 
naval officer who competed with them for seamen to man his ship and guns to arm it, as well as for prizes at sea. Jones's actions while in European waters demonstrate a genuine commitment to freeing imprisoned American sailors by capturing enemy sailors in order to effect prisoner exchanges. Few Continental Navy officers seem to have shared Jones's disdain for privateersmen, and several of them, including Elisha Hinman, John Manley, and Samuel Tucker, commanded privateers when prospects for active employment in the navy evaporated.

Two classes of captures sullied the reputation of Revolutionary War privateers: the seizing of American-owned vessels, and depredations on neutral vessels. A privateer bearing a commission had the right to stop, board, and examine any private ship it encountered outside neutral waters. On reviewing the logbook and ship's papers, the privateer captain had to determine whether or not the vessel was the property of an inhabitant of the enemy country and thus liable to seizure. That determination was not always self-evident, given the prevalent use of false papers. If anything appeared suspicious, such as the ship's papers being incomplete or containing inconsistencies, or if the logbook indicated the ship had called at an enemy port, the privateer captain might seize the vessel and send it into port on the possibility that the admiralty court would find it a good prize. ${ }^{36}$ In making these judgments, privateersmen made mistakes and sometimes took advantage of the slightest irregularity to justify a seizure. In either case, they created domestic foes of privateering.

Violations by American privateers of international law, ranging from confiscating British property found in neutral vessels - the Continental Congress supported the doctrine of "free ships make free goods" - to seizure of neutral vessels, moved the Continental Congress in 1778 to issue a proclamation enjoining American armed vessels to respect the rights of neutrals and in 1781 to produce new instructions to privateers augmented with directions spelling out the nature of neutral rights. Although not a large proportion of American captures, any capture of a neutral vessel posed international complications for the Revolutionary cause. One of the most notorious of these captures was made in 1778 by a Massachusetts privateer in which two delegates to Congress, Robert Morris and Virginia's Carter Braxton, were shareholders. The privateer captain of the schooner Phoenix made prize of a Portuguese merchantman, believing that, given that the Portuguese were allies of the British, Portuguese ships were therefore fair game for Americans. ${ }^{37}$

When the perpetrator of a questionable seizure was a New England privateersman and the victim a Southern ship owner, some feared inter-regional conflict. "Unless some measures are immediately taken to prevent the infamous practices of the Privateers," Baltimore's William Hooper warned Joseph Hewes, of North Carolina, "America will soon be in a state of general confusion-One Part warring against another, and the defenseless Southern colonies become a devoted prey to their more formidable Eastern neighbors. ${ }^{38}$ Robert Morris concurred with Hooper, writing to him,

36 Bourguignon, The First Federal Court, and Petrie, The Prize Game.

37 Allen, Massachusetts Privateers, 35-36.

38 William Hooper to Joseph Hewes, 1 Jan. 1777, Clark, Naval Documents of the American 
In all the Transactions of America nothing has given me more Concern than that kind of irregular Conduct on b[oar]d the Am[erican] Privateers that savours more of Moorish Piracy than Christian Forbearance. We have already many Instances that ought to be reprobated and the perpetrators bro[ugh]t to a Condign Punishment if the United States of Am[eric]a means to preserve a National good Character. . . unless we wish to plunder one another \& lay all the World under Contribution as a lawless set of Freebooters. $^{39}$

The number of improper captures of American-owned merchantmen by privateers was not large, but any such captures quickly became notorious, especially when the owner of the victimized vessel happened to be a member of the Continental Congress, such as Joseph Hewes.

Robert Morris's attitude toward privateering was conflicted. In September 1776 he wrote that privateering was a business that "does not square with my Principles." Having had long and extensive dealings with many English merchant houses, he felt uneasy in taking their property, even though their government had seized his. ${ }^{40}$ Not three months later, however, Morris purchased a one-third share in a West Indies privateer, enjoining the agent to keep the investment secret. "You must know," he wrote,

I had determined not to be Connected in privateering but having had several Vessels taken from me \& otherways lost a great deal of my property by this War, I conceive myself perfectly justifiable in the Eyes of God or Man to seek what I have lost, from those that have plundered me. ${ }^{41}$

While Morris may have been unusual in his hypocrisy, many shared his ambivalence about privateering.

A letter written by Mansel Alcock, a purchasing agent for the Continental Army on Cape Ann, in Massachusetts, to Timothy Pickering, a member of the army's Board of War, in the spring of 1778 suggests a similar ambivalence. Pickering's servant, Joseph Millet, had apparently complained to Alcott that the army was having trouble recruiting because so many young men were at sea on privateering cruises. As to whether privateering was truly harmful to the army, Alcock was of two minds.

Millets Accounts have made me from a Warm Advocate for Privateering almost a Convert to the Interests of the Army, I shoud always have been so, but I had such a high Opinion of Our Virtue \& Our strength, that I only look't on Privateering as the exuberance of both, but I find my self mistaken, stand rectified in my Opinion \& shall act accordingly, tho' I cant entirely give up Privateering.

In favor of privateering, Alcock reported, with unconcealed irony, that one of the

Revolution, VII: 838-839.

39 Robert Morris to William Hooper, 24 Jan. 1777, ibid., VII: 1031-1032.

40 Robert Morris to Silas Deane, 12 Sept. 1776, ibid., VI: 794.

41 Robert Morris to William Bingham, 4 Dec. 1776, ibid., VII: 368-369. 
"PIRATICAL Privateers" had captured a rich prize, the cargo of which would help provide the army with much needed supplies. He believed that if the army offered high enough pay, enlistment bounties, and promise of further reward at the end of the war, there were enough landsmen in America to fill the army's recruiting needs so that there would be no need to keep port towns from sending their men out to cruise against enemy commerce, in the face of "the most Potent Maritime Nation that ever existed in the World." $" 42$

Alcock also reported a debate in the Massachusetts Council on a motion to discontinue the issuing of commissions to small privateers. The supporters of the motion, apparently members of Salem's Derby family, characterized the privateers as pirates, whereas the opponents defended the privateers as legitimately commissioned by the state. The "ostensible pretence" of the motion to stop privateering was that the privateers hurt America's friends in Nova Scotia; the real motive behind the motion, however, according to popular understanding, was to keep the privateers from interfering with clandestine trade between Massachusetts and Nova Scotia.

Alcock's letter touches on the major elements in the American debate about privateering. Critics of the practice argued that privateers: behaved like pirates; drew too many men away from enlisting in the army and navy; hurt supporters of the patriot cause in Canada, and; were motivated not by love of country but by private plunder. Whereas proponents argued that: privateering was a legitimate form of warfare; privateers helped the war effort by striking at the enemy's commerce and were America's most effective weapon against the Royal Navy; the cargoes of prizes that privateers sent into port were important sources of scarce supplies for both military and civilian uses; the army's recruiting difficulties arose not from privateering but from insufficient incentives to enlist; privateersmen were brave and heroic patriots who risked death for the sake of their country's freedom, and; rather than being patriots, critics of privateering might be seeking to protect the profits of trade with the enemy.

A few weeks after Alcock's letter to Pickering, New Hampshire's delegates to the Continental Congress, Josiah Bartlett, attending Congress in York and later Philadelphia, Pennsylvania, and William Whipple, writing from home in Portsmouth, began an epistolary discussion of the merits and demerits of privateering that lasted through the month of July 1778. This discussion merits analysis because it is the one sustained discussion between delegates to Congress of which we have record. Whipple, trying to change a policy in place, developed his argument more fully than did Bartlett, who marshaled the standard arguments in favor of privateering without presenting a detailed defense. Whipple brought together all the chief elements of the anti-privateering argument. According to Whipple, privateering promoted vice. Its officers were either "the most profligate fellows," or, if one was originally of "a fair moral character," he soon "degenerates and falls into all the vices of his associates." It introduced "Luxury, Extravagances, \& every kind of Dissipation, that tend to the destruction of the Morals of the people." Privateering, he asserted, stimulated insatiable avarice that led inevitably to

42 Mansel Alcock to Timothy Pickering, April 1778, Timothy Pickering Papers, vol. 17, Massachusetts Historical Society, Boston, MA. 
freebooting. The privateers would surely "disgrace the American flag," and, not satisfied with the property of the enemies of their country, they would "without the least compunction seize that of her Friends." Privateering hurt recruiting for both the army and the navy. Because of the absence of so many men either engaged in privateering or captured in privateers and held prisoners by the enemy, towns were obliged to give huge enlistment bounties to reach their quotas of soldiers for the army. The rage for privateering had left Major General John Sullivan, for example, with an army of a mere five hundred soldiers with which to oppose British ravages in Rhode Island. Continental Navy warships lay along the wharfs half-manned. Men entrusted with naval affairs were involved in privateering and placing their private interests above that of the public. They manned their own ships before the public's, even encouraging desertion from the Continental Navy. They treated Continental Navy officers with contempt, discouraging gentlemen of ability from accepting public service. Finally, privateering hurt agriculture. It drove up the cost of farm labor, for with so many seamen being captured by the enemy, the privateers had turned to recruiting young men from the countryside, and the increased cost of farm labor, in turn, drove up the price of provisions. To prevent these evils, Whipple called for an immediate and total stoppage to privateering. ${ }^{43}$

In his reply, Bartlett, one of the early advocates of privateering, defended the practice, asserting "privateers have done more towards distressing the trade of our enemies and furnishing these States with necessaries, than continental ships of the same force." As commerce raiding was also the best use of the public vessels of war, since the Continental Navy was too small to cope directly with the Royal Navy, it was a public benefit to have private warships cruising for enemy merchantmen as well. ${ }^{44}$

Whipple answered Bartlett's assertion with the argument that, in the absence of competition for seamen from privateers, a greater number of the public's ships would have been fitted out, would have captured nearly as many prizes, and would have "furnished these states with necessaries on much better terms than they have been supplied by Privateers." 45

Although Bartlett stated that he was "fully sensible to the force of Whipple's arguments," he was not persuaded. He thought it would be beneficial to restrain privateering within proper bounds; but, like Alcock, who could not "entirely give up Privateering," Bartlett was "not quite satisfied that a total prohibition would be

43 William Whipple to Josiah Bartlett, 3 May 1778, private collection, J.G.M. Stone, Annapolis, MD, 1959; William Whipple to Josiah Bartlett, 1 June 1778, in The American Pioneer, A Monthly Periodical ... of the Logan Historical Society, 2 vols. (Chillicothe and Cincinnati, OH, 1842-43), II : 20-21; Historical Society of Pennsylvania, Philadelphia, PA, William Buell Sprague Autograph Collection, vol. 1, William Whipple to Josiah Bartlett, 21 June 1778; New York Public Library, New York, NY, Emmet Autograph Collection, William Whipple to Josiah Bartlett, 12 July 1778.

44 Library of Congress, Washington, DC, Peter Force Transcripts, William Whipple Papers, Josiah Bartlett to William Whipple, 20 June 1778.

45 New York Public Library, New York, NY, Emmet Autograph Collection, William Whipple to Josiah Bartlett, 12 July 1778. 
serviceable." $" 46$

William Whipple introduced a moral argument against privateering, suggesting its connection with vice and dissipation. But it took a member of the Society of Friends, committed to the Quaker peace testimony, to give the moral argument its full force. William Rotch was a leading ship owner of Nantucket, Massachusetts, whalers and, like many of his fellow inhabitants of the island, a Quaker. Late in November 1776 he complained to prominent Providence merchant Nicholas Brown that the captain and crew of a privateer sloop had seized a schooner of Rotch's on specious pretenses and "in a Ruffian like manner ... with Swords and guns." Rotch did not know the sloop's name, but reported, "she is known here by the Name of the Willfull Murther, an appellation not very unbecoming the carrecteristick of her crew." Believing that the privateer belonged to Brown, Rotch took the opportunity to give the merchant a sermon on Christian charity.

If you are concern'd in the Privateering business, I beg you to consider the consequences of it, \& how often honest Men are deprived of their Rights. . . . endeavour to bring to View the cries of innocent parents \& their tender Offspring, perhaps for the want of Bread, for the reality of this let any man cast his Eyes on some parts of Nova Scotia Government, where the Calamitous situation of some of our real friends \& Country men that are settld there, brot on them by the Destruction from privateers, must be a very moving scene to a mind susseptible of but a small degree of Humanity. ${ }^{47}$

Records do not reveal whether Rotch's schooner had been involved with trading with the enemy and thereby liable to capture, but there is good reason to believe that his opposition to privateering was principled rather than self-interested. Quakers opposed any kind of prize taking and Rotch's arguments were as applicable to commerce raiding by commissioned naval vessels as they were to privateering. Serving with a privateer was a disciplinary offence within the Society of Friends, just as was enlisting in the navy, but so was the purchasing of prize goods at an admiralty court's sheriff's auction, whether they had been taken by a privateer or a naval vessel. Friends condemned buying prize goods on the same grounds they opposed the buying of slaves: they both involved dealing in stolen goods. Rotch, himself, was an active opponent not only of privateering, but also of slavery, having engaged John Adams's legal services in a successful suit to free a Nantucket man from slavery. ${ }^{48}$ Rotch's argument against privateering as immoral is significant because it foreshadows the arguments used by advocates of the peace movement, largely Unitarians, who agitated for the banning of privateering after the War of $1812 .^{49}$

46 Library of Congress, Washington, DC, Peter Force Transcripts, Alfred Langdon Elwyn Collection, Josiah Bartlett to William Whipple, 27 July 1778.

47 William Rotch to Nicholas Brown, 26 Nov. 1776, Clark, Naval Documents of the American Revolution, VII: 292-293.

48 Thomas E. Drake, Quakers and Slavery in America (1950; reprint ed., Gloucester, Mass.: Peter Smith, 1965), 88.

49 "Application to Abolish Privateering in Time of War," petition of the Plainfield, MA, Peace Society, to Congress, 27 Dec. 1819, and "Application to Abolish Privateering in Time of 
Perhaps the most powerful antidote to the villainous portrait of privateersmen limned by their detractors came in the form of deeds of heroism and bravery performed by privateersmen. When a state issued a letter of marque to a privateer captain, there was a presumption, seldom verbalized, that the privateers were not solely private moneymaking undertakings, but held a certain obligation to serve the public interest. There were unwritten, but real, expectations of privateers. Privateers, for instance, were expected to defend merchantmen from a less powerful armed enemy vessel. ${ }^{50}$ If two privateers were sailing within sight of each other, it was expected that they would engage an enemy in tandem. For one to stand off would be despised as base cowardice. ${ }^{51}$ During the Revolution, some privateers did in fact directly protect their home ports. For instance, in the spring of 1782, a Royal Navy raiding party cut out the Harriot, a ship laden with a valuable cargo and ready for sea, from the harbor of Gloucester, Massachusetts Immediately, the residents began fitting out and arming the Polly, a twenty-four gun privateer, "then on the ways and with her topmasts struck." Within four hours "she was complete for sea." The Polly caught up with and the officers and crew retook the Harriot, with which they returned, "to their own honour and the satisfaction of the inhabitants." 52 Although many privateersmen failed to live up to these standards, patriotic deeds of daring by American privateers fill the annals of the Revolution.

Officers of the Continental and state navies took their sense of public trust with them into privateer service. John Manley, for instance, in the eighteen-gun ship Jason unhesitatingly attacked a pair of British privateer brigs, of eighteen and sixteen guns, taking both. ${ }^{53}$ Jonathan Haraden, a captain in the Massachusetts State Navy, made a name for himself in an engagement with much larger and better-armed vessel. As the Independent Chronicle of 17 August 1780 reported the sea fight,

A most violent contest ensued and continued for two hours and a half, during which time the Captain, officers and crew of the Pickering managed their ship with such address and fought with such unexampled bravery and heroism that the Lugger, large and stout as she was, was glad to leave them.

Haraden's ship, the privateer General Pickering, carried sixteen guns and one hundred men; its opponent carried forty-three guns and 130 men. $^{54}$

The patriot press reported like incidents in glowing terms, stating that the gallant actions won "the applause of the public." 55 Favorable mention of privateersmen

War," petition of inhabitants of Massachusetts to Congress, 26 Jan. 1820, in American State Papers, 6, Naval Affairs, 1: 643-44, 723-32.

50 Howard M. Chapin, Privateering in King George's War, 1739-1748 (Providence, RI, 1928), 39.

51 Christopher Prince, The Autobiography of a Yankee Mariner: Christopher Prince and the American Revolution, edited by Michael J. Crawford (Washington, DC, 2002), 181-183.

52 Allen, Massachusetts Privateers, 240-241.

53 Ibid., 191-192.

54 Ibid., 150-151.

55 Ibid., 93; see also 118-19, 186, 241. 
frequently appeared in the patriot newspapers. Consider this privateersman's obituary that appeared in the New Jersey Gazette of 25 September 1782:

Died, September 6, 1782, . . the brave Captain Adam Hyler of New Brunswick. His many enterprising acts in annoying and distressing the enemy endeared him to the patriotic part of his acquaintance. . . . His remains were decently interred with a display of the honors of war in the old Dutch burial ground, attended by a very numerous concourse of his acquaintances.

Since 1780, the Trenton New Jersey newspaper had closely followed Hyler's career of daring raids in small boats on British shipping in New York waters. ${ }^{56}$

John Adams thought, "Some of the most skillful, determined, persevering, and successful engagements that have ever happened upon the seas have been performed by American privateers against the privateers of New York." ${ }^{57}$

Privateersmen were generally an unreflective lot and their writings were mainly routine documents relating to the practical business of commerce cruising. A few, however, left behind journals that give insight into their self-perception. In his autobiography, Connecticut sailor Christopher Prince may speak for the majority of his fellow privateersmen when he gives a candid and plausible assessment of his motivation. At the close of the war he wrote, "through the whole course of the war I have had two motives in view, one was the freedom of my country, and the other the luxuries of life." 58

As much as anything else this mixture of patriotism and personal profit accounts for the two faces, hero and knave, that privateersmen wore in the popular imagination during the American Revolution. The admixture explains why privateersmen sometimes exposed themselves to great peril in engaging the enemy when the prospects of booty were minimal, and at other times sacrificed the public good for sake of private pelf.

John Adams, who was one of privateering's staunchest advocates, Josiah Bartlett, who favored privateering while admitting that its abuses should be regulated, Robert Morris, who had his reservations about privateering but embraced it nonetheless, and William Whipple, who preferred that a stop be put to privateering altogether, were all signatories of the Declaration of Independence and represent the spectrum of attitudes toward privateering found among leaders of the American Revolution. A survey of the correspondence of the fifty-six signers of the Declaration of Independence published in the twenty-six-volume Letters of Delegates to Congress, 1774-1789 uncovers the stated views on the subject of twelve of these men. William Whipple appears as the only delegate who proposed an outright end to the practice. Benjamin Rush, of Pennsylvania, wanted a curtailment of letters of marque because privateering hurt army recruiting. Joseph Hewes, of North Carolina, had grievances against a Massachusetts privateer for capturing two of his merchantmen but yet did not call for abolition. A greater number of

56 George Moore, "Privateering in New York Harbor," unpublished essay, Naval History and Heritage Command, Early History Branch files.

57 Allen, Massachusetts Privateers, 16-17.

58 Prince, Autobiography of a Yankee Mariner, 210. 
signers clearly favored privateering. Samuel Chase, of Maryland, was an early advocate of authorizing privateering, and George Wythe, of Virginia, drafted a preamble (not adopted) to the original resolution in the Continental Congress that authorized privateering, defending it as just retaliation. Benjamin Franklin saw privateering as a means to draw more seamen into the Revolutionary cause and used his authority as American minister in France to issue letters of marque. Although the schooners George Washington employed to prey on British transports in Massachusetts Bay were not technically privateers, he thought of them as such. Besides Morris, at least two other signers, Elbridge Gerry, of Massachusetts, and Carter Braxton, of Virginia, invested in privateering cruises. ${ }^{59}$

On the positive side of the balance sheet, some revolutionary Americans wholeheartedly endorsed privateering because they believed the practice advanced the cause of independence by taking the war to the enemy on the sea. On the negative side, others condemned privateering for the many problems it caused. Most American patriots, it seems, stood with Mansel Alcock and Josiah Bartlett, who accepted the practice as a useful means of carrying on the war and only thought measures should be taken to restrain its excesses. The delegates to the Continental Congress proved slow in regulating privateering. Only late in the war, on 21 May 1782, in response to complaints from Jonathan Trumbull, governor of Connecticut, did Congress authorize state executives to suspend the commission of privateer captains accused of illegal intercourse with the enemy "or of any other mal-conduct." ${ }^{60}$ After the Continental Congress authorized commerce raiding by private armed ships, at no point during the war did opposition pose any real threat of putting a stop to privateering.

59 Letters of Delegates to Congress, 1774-1789, edited by Paul H. Smith, et al., 26 vols. (Washington: Library of Congress, 1976-2000) III: 252, 375, 427, V: 277-81, 640, VI: 7-9, VIII: 155-56, XIII: 158; Morgan, "American Privateering in America's War for Independence," 80.

60 U.S. Continental Congress, Journals of the Continental Congress, 1774-1789, edited by Worthington C. Ford and Gaillard Hunt, 34 vols. (Washington: Library of Congress, 190437), XXII: 280-81. 